\title{
Interleukin 16 Measurement
}

National Cancer Institute

\section{Source}

National Cancer Institute. Interleukin 16 Measurement. NCI Thesaurus. Code C74812.

The determination of the amount of interleukin 16 present in a sample. 